\title{
Determination of Trace Amount of Cadmium by Atomic Absorption Spectrometry in Table Salt after Solid Phase Preconcentration Using Octadecyl Silica Membrane Disk Modified by a New Derivative of Pyridine
}

\author{
Mahmood Payehghadr, ${ }^{1}$ Sousan Esmaeilpour, ${ }^{1,2}$ \\ Mohammad Kazem Rofouei, ${ }^{3}$ and Laleh Adlnasab ${ }^{4}$ \\ ${ }^{1}$ Department of Chemistry, Payame Noor University, Tehran 19395-4697, Iran \\ ${ }^{2}$ Standard Research Institute, Karaj 31585-163, Iran \\ ${ }^{3}$ Faculty of Chemistry, Tarbiat Moallem University, Tehran 15815-3587, Iran \\ ${ }^{4}$ Department of Chemistry, Shahid Beheshti University, Evin, Tehran 1983963113, Iran \\ Correspondence should be addressed to Mahmood Payehghadr; mahmood_payehghadr@yahoo.com
}

Received 19 December 2011; Accepted 5 June 2012

Academic Editor: Ahmed Mourran

Copyright (C) 2013 Mahmood Payehghadr et al. This is an open access article distributed under the Creative Commons Attribution License, which permits unrestricted use, distribution, and reproduction in any medium, provided the original work is properly cited.

\begin{abstract}
Silica-C18 bonded disk modified by a four-dentate Schiff base has been used for preconcentration of cadmium in table salt samples followed by flame atomic absorption spectrometry. The method is based on the adsorption of Cd on 1,2-bis(pyridin2-ylmethylene) hydrazine as Schiff base ligand on silica-C18 disk. The effects of several factors such as type and concentration of the eluent, $\mathrm{pH}$ of sample solution, amount of ligand, and breakthrough volume have been optimized based on one variable at a time. In optimum conditions (type of eluent, $\mathrm{HNO}_{3} 1.0 \mathrm{~mol} / \mathrm{L}$; volume of eluent, $5.0 \mathrm{~mL}$; solution $\mathrm{pH}$, 9.0; breakthrough volume, $1000.0 \mathrm{~mL}$ ), preconcentration factor of the present method is about 200. The resultant limit of detection is $5.0 \mu \mathrm{g} / \mathrm{L}$. Finally, the performance of the method has been evaluated for extraction and determination of Cd (II) in salt samples at milligram per liter concentration, and satisfactory results have been obtained (RSD $\leq 2.0 \%)$.
\end{abstract}

\section{Introduction}

The contamination of food with heavy metals could cause acute poisoning as well as long-term health problems. Table salt is an essential additive which is frequently added to certain foods for improving the taste, and it is used as a preservative as well. Therefore, due to the daily consumption of table salt, any contamination even in low level could put the consumer's health at risk. In fact, heavy metal ions are toxic, non-biodegradable, and tend to be accumulated in the human vital organs, where they can act progressively over a long period through food chains $[1,2]$, and the reported primary adverse health effects of them are lung cancer and kidney damage $[3,4]$. Among these heavy metals, cadmium is one of the most toxic elements for human and animals, even at low concentrations, and the International Agency for Research on Cancer classified $\mathrm{Cd}$ as a human carcinogen [5]. The FAO/WHO (Food and Agriculture Organization/World Health Organization) and Joint Expert Committee on Food Activities recommended maximum tolerable daily intake of cadmium from all sources (food, air, and water) of 1.0-1.2 $\mu \mathrm{g} / \mathrm{g}$ weight of body [6]. In Codex standard the permissible level of cadmium in table salt is $0.2 \mu \mathrm{g} / \mathrm{g}$.

Because of the complexity of sample matrix and low concentrations of cadmium in the environmental samples, preconcentration and matrix-removal steps are required to guarantee the accuracy and precision of the analytical 
results $[1,5,7]$. Many preconcentration methods followed by different quantitative instrumental techniques have been investigated in trace heavy metal in the environmental samples [8].

Although atomic absorption spectroscopy (AAS) and inductively coupled plasma atomic emission spectroscopy (ICP-AES) are the most widely used methods, their sensitivity is usually insufficient for monitoring the low level concentration of these ions in the environmental samples [9-12]. Therefore, element with lower concentrations than the detection limits of the instrumental techniques are a serious problem in the trace heavy metal determination in the environmental samples [13]. The most common techniques reported for preconcentration of Cd (II) are liquid-liquid extraction (LLE) $[14,15]$, solid-phase extraction (SPE) [16, $17]$, ion exchange [18], cloud point extraction $[19,20]$, and electroanalytical techniques [21].

Solid-phase extraction (SPE) has advantages over other preconcentration methods in terms of simplicity, economy, rapidity, reusability of the adsorbent, ease of automation, higher preconcentration factor, lower consumption of reagents, and, more importantly, its environmental friendliness (use of less organic solvents). The most extensively used SPE sorbents are modified C-18 silica [22], activated carbon [23], alumina [24], and Amberlite XAD resins [25, 26]. For example, silica and silica-bonded adsorbents offer good advantages in terms of thermal, mechanical, and chemical stability. In addition, they act selectively towards a particular metal ion. In fact, the modified silica gel surfaces are known to act as a weak cation exchanger via its weak silanol groups, through immobilization of organic complexing agents, either chemically or physically. These modified surfaces greatly enhance metal exchange capacity and improve selectivity of these phases to metal ion removal, separation, or preconcentration prior to their determination by X-ray fluorescence or AAS analysis [11,27-30]. Chelating agents can be easily loaded on silica-bonded adsorbents with good stability and Schiff bases often used as chelating ligands and their metal complexes have been of great interest for many years. Chelating ligands containing $\mathrm{N}, \mathrm{S}$, and $\mathrm{O}$ donor atoms are of special interest because of the various ways in which they are bonded to the metal ions. The variety of possible Schiff base metal complexes with wide choices of ligands and coordination environment has encouraged us to choose a tetradentate Schiff base for modifying the adsorbent disk. The mobilization and immobilization of cadmium have been shown to depend significantly on the complexation of the metal center by chelating nitrogen donor ligands [8,31-33].

In the present method, octadecyl silica disk modified with a new derivative of pyridine ligand (tetra-dentate Schiff base), (Figure 1) which is followed by flame atomic absorption spectrometry, has been applied for preconcentration and determination of cadmium in salt samples because of the toxic environmental impact of $\mathrm{Cd}$. The effects of different variables such as type and concentration of eluent, sample solution $\mathrm{pH}$, concentration of ligand, and effect of breakthrough volume have been investigated and optimized based on the method of one variable at a time. In the end, the

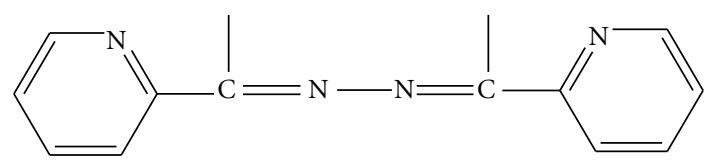

FIGURE 1: Structure of (1,2-bis(pyridin-2-ylmethylene) hydrazine) ligand.

optimized method has been applied for determination of $\mathrm{Cd}$ ions in real samples.

\section{Experimental}

2.1. Chemicals and Reagents. Acetonitrile (ACN), methanol, nitric acid, ethylene diamine tetraacetic acid (EDTA), acetic acid, sulfuric acid, hydrochloric acid, phosphoric acid, sodium dihydrogen phosphate, ammonium acetate, ammonia solution, and ammonium chloride salt are of analytical grade from Merck (Darmstadt, Germany). Double distillated water has been prepared by Mili-Q system from Millipore (Bedford, MA, USA).

Reference standard solution of cadmium having the metal concentration of $1000.0 \pm 2.0 \mathrm{mg} / \mathrm{L}$ in $2 \%(\mathrm{v} / \mathrm{v})$ of $\mathrm{HNO}_{3}$ have been purchased from assurance company. The working standard solutions have been prepared by appropriate dilution of the stock solution with double distillated water, all solutions have been stored in ambient temperature. The new synthesized Schiff base (Figure 1) with highest purity has been used as the chelating ligand.

Reference standard solutions of $\mathrm{As}, \mathrm{Hg}, \mathrm{Pb}, \mathrm{Na}, \mathrm{K}, \mathrm{Ca}$, and $\mathrm{Mg}$ (each of them $1000.0 \pm 2.0 \mathrm{mg} / \mathrm{L}$ in $2 \%(\mathrm{v} / \mathrm{v})$ of $\mathrm{HNO}_{3}$ ) have been bought from Merck company.

For preparing $\mathrm{pH} 2.0$ and 3.0 buffer solutions, appropriate amount of phosphoric acid has been added to sodium dihydrogen phosphate solution $(0.1 \mathrm{~mol} / \mathrm{L})$. Moreover, appropriate amount of acetic acid has been added to ammonium acetate solution $(0.1 \mathrm{~mol} / \mathrm{L})$ to give buffer solutions of $\mathrm{pH}$ 4.0-6.0. Titrisol buffer solution from Merck $\left(\mathrm{C}\left(\mathrm{KH}_{2} \mathrm{PO}_{4}\right)=\right.$ $0.026 \mathrm{~mol} / \mathrm{L}$ and $\left.\mathrm{C}\left(\mathrm{Na}_{2} \mathrm{HPO}_{4}\right)=0.041 \mathrm{~mol} / \mathrm{L}\right)$ has been used as $\mathrm{pH}$ 7.0, and an ammonium ammonia buffer solution has been prepared by adding an appropriate amount of ammonia to ammonium chloride solution $(0.1 \mathrm{~mol} / \mathrm{L})$ to give a solution of $\mathrm{pH} 8.0-10.0$.

2.2. Instrumentation. A Varian model AA- 1275 flame atomic absorption spectrometer with a deuterium background corrector was used for determination of Cd ions, and a cadmium hollow cathode lamp was used as light source operated at $3.5 \mathrm{~mA}$. The wavelength was set at $228.8 \mathrm{~nm}$ resonance line and the spectral band pass at $0.5 \mathrm{~nm}$, and the measurements were carried out in an air/acetylene flame. A digital $\mathrm{pH}$ meter, Mettler Toledo model MP225, equipped with a combined glass calomel electrode was used for the $\mathrm{pH}$ adjustments.

Extraction was performed with $47 \mathrm{~mm}$ diameter $\times$ $0.5 \mathrm{~mm}$ thickness Empore membrane disks containing octadecyl-bonded silica ( $8 \mu \mathrm{m}$ particle, $60-\AA$ pore size, $3 \mathrm{M}$ Co., St. Paul, MN) with a standard Millipore $47 \mathrm{~mm}$ filtration 
apparatus. The twin cylinder vacuum pump model of TC$2000 \mathrm{~V}$ (Taiwan) was used to provide the required pressure for extraction.

2.3. Extraction Procedure. The membrane disk was conditioned with $20.0 \mathrm{~mL}$ of methanol and $20.0 \mathrm{~mL}$ of water, respectively, to remove all contaminants arising from the manufacturing process and the environment. The disk was dried by passing the air through it for several minutes, and then $8 \mathrm{mg}$ of ligand was dissolved in $3.0 \mathrm{~mL}$ ACN and passed through sorbent several times under gravity until the ligand penetrated the membrane completely. Then modified disk was applied for extraction step, $100.0 \mathrm{~mL}$ of standard solution containing $10.0 \mu \mathrm{g}$ of $\mathrm{Cd}$ was prepared, and solution $\mathrm{pH}$ was adjusted with buffer solution at 9.0. Afterwards, this solution was loaded at a flow rate of about $4.0 \mathrm{~mL} / \mathrm{min}$ with the aid of a vacuum pump, and the retained $\mathrm{Cd}$ ions were eluted with $5.0 \mathrm{~mL}$ of $\mathrm{HNO}_{3}(1.0 \mathrm{~mol} / \mathrm{L})$ under gravity (about $2.0 \mathrm{~mL} / \mathrm{min}$ ) followed by FAAS for determination of $\mathrm{Cd}$ content. Five measurements were made for each sample and the results were subsequently averaged. After each extraction, the disk eluted with two times $5.0 \mathrm{~mL}$ of $\mathrm{HNO}_{3}(1.0 \mathrm{~mol} / \mathrm{L})$ and with $5.0 \mathrm{~mL}$ of water, respectively.

2.4. Sample Preparation. One salt sample from mine (Rahrahak mine, Iran) and a commercial sample from Iranian market were collected as the real samples. 2.0 gr table salt was dissolved in $60.0 \mathrm{~mL}$ double distillated water, and solution $\mathrm{pH}$ was adjusted to 9.0 with $5.0 \mathrm{~mL}$ of ammonium chloride/ammonia buffer solution and diluted to $100.0 \mathrm{~mL}$ with water. This solution was applied for the preconcentration step.

\section{Results and Discussion}

In the proposed method, solid phase extraction with silicaC18 disk, modified by a four-dentate Schiff base, which is followed by FAAS determination was applied for preconcentration of Cd ions in salt samples. An azine compound (1,2bis(pyridin-2-ylmethylene)hydrazine), (Figure 1), was used as a selective chelating ligand for cadmium complexation. The effect of different parameters on the extraction and elution of $\mathrm{Cd}$ ions was optimized by using the method of one variable at a time.

3.1. Effect of Solution $p H$. Among chemical variables, $\mathrm{pH}$ is seemed to be the most important parameter for adsorption of the metal ions on ligand. As Schiff bases are conjugate bases of weak acid groups, they have very strong affinity for hydrogen ions. The $\mathrm{pH}$ of solution will determine the values of conditional stability constants of metal complexes on the surface of the sorbent. In order to assess the effect of solution $\mathrm{pH}$ on extraction efficiency, the $\mathrm{pH}$ of $100.0 \mathrm{~mL}$ model solutions containing $0.1 \mathrm{mg} / \mathrm{L}$ of $\mathrm{Cd}$ ions was adjusted in the range of 3.0-10.0 with different buffer solutions. The retained Cd ions were eluted with $5.0 \mathrm{~mL}$ of $\mathrm{HNO}_{3}(1.0 \mathrm{~mol} / \mathrm{L})$ followed by FAAS for determination of $\mathrm{Cd}$ content. Figure 2 reveals that extraction recovery of the analyte grows significantly by

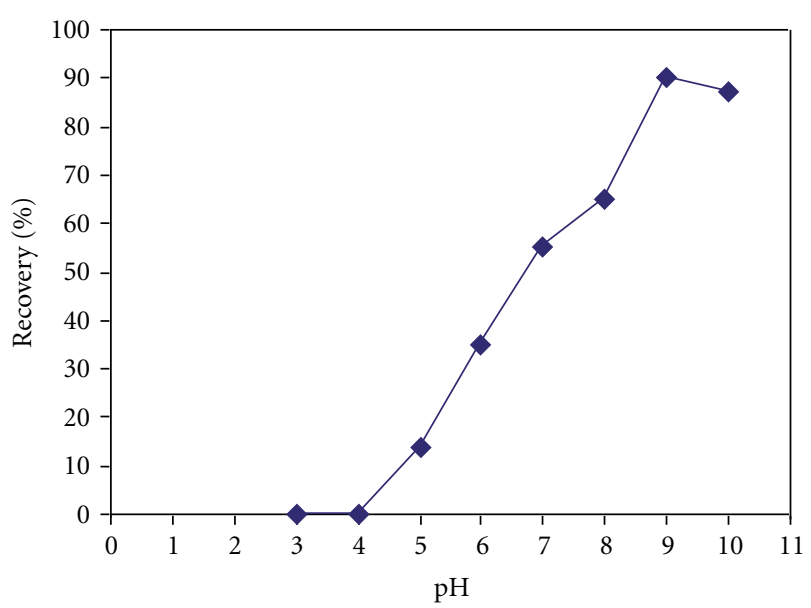

FIGURE 2: Effect of solution $\mathrm{pH}$ on recovery (\%) (extraction conditions: sample volume, $100.0 \mathrm{~mL}$; eluent solvent, $5.0 \mathrm{~mL}$ of $\mathrm{HNO}_{3}(1.0 \mathrm{~mol} / \mathrm{L})$; amount of ligand, $8 \mathrm{mg}$; concentration of $\mathrm{Cd}$ ion, $0.10 \mathrm{mg} / \mathrm{L})$.

increasing the $\mathrm{pH}$ of sample solution, but it is important to know that the $\mathrm{pH}$ higher than 10.0 may cause the destruction of the disk. Therefore, $\mathrm{pH}=9.0$ was selected as the best $\mathrm{pH}$ in the subsequent experiments.

3.2. Effect of Type and Concentration of Eluent. Complete stripping of $\mathrm{Cd}$ ions from ligand was examined with several eluents such as $\mathrm{H}_{2} \mathrm{SO}_{4}, \mathrm{HNO}_{3}, \mathrm{HCl}$, and EDTA. In fact, the selection of the eluent was really difficult due to the limitation of FAAS to tolerate organic solvents, and the eluent should not destroy the solid phase. In lower $\mathrm{pH}$, the ligand-Cd complex dissociates to release $\mathrm{Cd}$ ions. Therefore, acidic eluents are the best choice to obtain efficient extraction. According to the results in Figure $3, \mathrm{HNO}_{3}$ was selected as the best eluent. $\mathrm{HNO}_{3}$ at various concentrations was investigated for increasing recovery. The results show that $\mathrm{HNO}_{3}$ with $1.0 \mathrm{~mol} / \mathrm{L}$ concentration is the best solvent for elution of $\mathrm{Cd}$ ions.

3.3. Effect of Ligand Concentration. Prior to adsorption of trace heavy metal ions on a solid phase for preconcentration, metal ions were converted to a suitable form including metal chelates or metal inorganic complexes. Because of this, different concentrations of ligand were investigated for increasing extraction efficiency. Different amounts $(3,5,8$, and $10 \mathrm{mg}$ ) of ligand in $3.0 \mathrm{~mL}$ of $\mathrm{ACN}$ were added to the disk, and quantitative recoveries were obtained for cadmium ions with $8 \mathrm{mg}$ of ligand. In all further works, $8 \mathrm{mg}$ of ligand in $3.0 \mathrm{~mL}$ ACN solution was applied for modification of the disk.

3.4. Stability of Solid Phase. The reuse of the modified disk was tested for its ability to perform the SPE for more than one sample. It was found that the use of the same disk modified with Schiff base for at least twenty times did not change the recovery of $\mathrm{Cd}$ ion. In addition, there was no decrease 


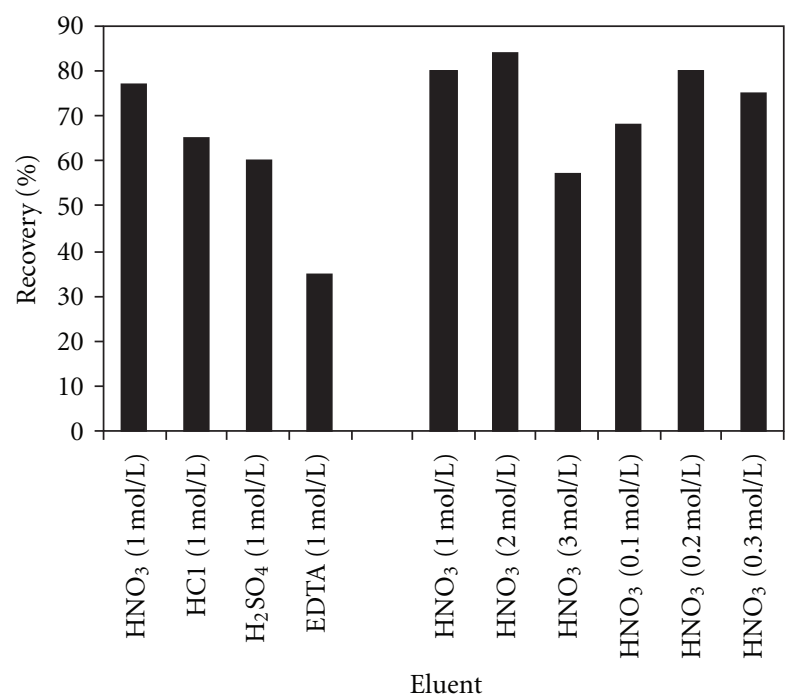

FigURE 3: Effect of type and concentration of eluent on recovery (\%), (Extraction conditions: sample volume, $100.0 \mathrm{~mL}$; amount of ligand, $8 \mathrm{mg}$; sample solution $\mathrm{pH}, 9.0$; concentration of Cd ion, $0.10 \mathrm{mg} \mathrm{L}^{-1}$ ).

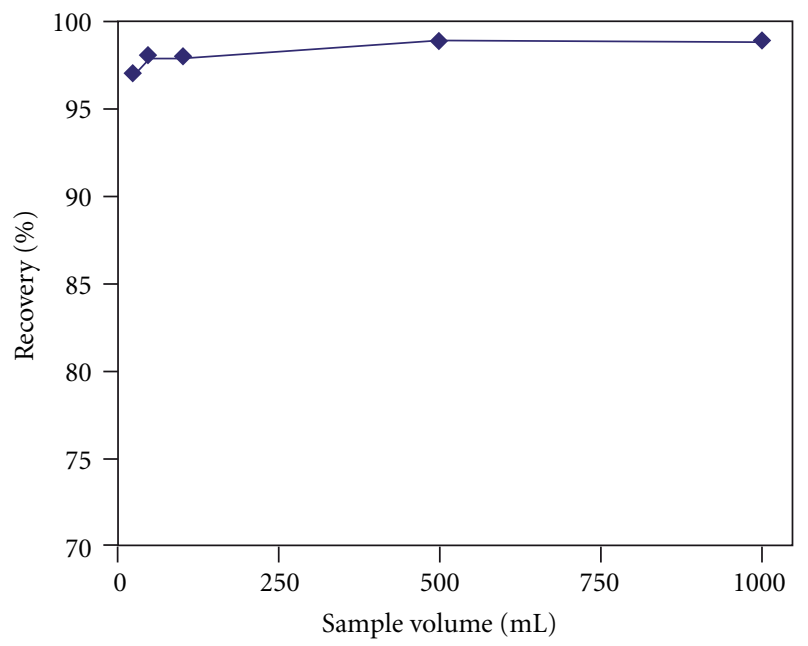

FIGURE 4: Effect of breakthrough volume on recovery (\%) (extraction conditions: eluent solvent, $5.0 \mathrm{~mL}$ of $\mathrm{HNO}_{3}(1.0 \mathrm{~mol} / \mathrm{L})$; amount of ligand, $8 \mathrm{mg}$; sample solution $\mathrm{pH}, 9.0$; concentration of Cd ion, $0.10 \mathrm{mg} \mathrm{L}^{-1}$ ).

in recovery for interday and intraday extractions. However, for the SPE of trace amounts of Cd from real samples, it is recommended to use a new modified disk for each sample to protect them from possible contaminations.

3.5. Effect of the Breakthrough Volume. The breakthrough volume of sample solution was tested by treating standard solutions containing $10 \mu \mathrm{g} \mathrm{Cd}$ ions with different sample volumes $(25.0,50.0,100.0,250.0,500.0$, and $1000.0 \mathrm{~mL})$. The effect of breakthrough volume on recovery has been showed in Figure 4. In all cases, the extraction by membrane disk was found to be quantitative. Thus, $1000.0 \mathrm{~mL}$ was the maximum sample volume in which quantitative extraction of $\mathrm{Cd}$ ions is
TABLE 1: Extraction of Cd ion from binary mixtures.

\begin{tabular}{lcc}
\hline Interference ion & $\begin{array}{c}\text { Concentration } \\
(\mathrm{mg} / \mathrm{L})\end{array}$ & $\begin{array}{c}\text { Recovery of Cd (II) } \\
(\%)\end{array}$ \\
\hline $\mathrm{Mg}^{+2}$ & 300 & $96.0 \pm 0.5$ \\
$\mathrm{Ca}^{+2}$ & 1500 & $95.0 \pm 1.0$ \\
$\mathrm{~K}^{+}$ & 100 & $94.0 \pm 1.0$ \\
$\mathrm{Hg}^{+2}$ & 100 & $94.0 \pm 1.0$ \\
$\mathrm{As}^{+3}$ & 100 & $95.0 \pm 0.5$ \\
$\mathrm{~Pb}^{+2}$ & 100 & $89.0 \pm 1.0$ \\
\hline
\end{tabular}

possible. Sample volume more than $1000.0 \mathrm{~mL}$ was not tested due to increase of extraction time. To reduce the extraction time, $100.0 \mathrm{~mL}$ sample solution was selected.

3.6. Sorption Capacity. The maximum capacity of the membrane disk modified by a new Schiff base ligand was determined by passing $50.0 \mathrm{~mL}$ of an aqueous solution containing $500.0 \mu \mathrm{g}$ Cd ions through the disk. The amount of the retained $\mathrm{Cd}$ ions determined using furnace atomic absorption spectrometry. The maximum capacity of the disk was found to be $325 \mu \mathrm{g}$ Cd ion per $8 \mathrm{mg}$ of ligand.

3.7. Influence of Interference Ions. The impact of a variety of cations found in salt samples on the determination of $\mathrm{Cd}$ has been studied. The limit of heavy metals $(\mathrm{Pb}, \mathrm{Cd}$, As, $\mathrm{Hg}, \mathrm{Cu}, \mathrm{Fe})$ and other cations $\left(\mathrm{K}^{+}, \mathrm{Mg}^{2+}, \mathrm{Ca}^{2+}\right)$ is determined in Codex standard for table salt. Therefore, the above-mentioned cations have been chosen for the investigation of interference ions. For this purpose, $\mathrm{Na}^{+}, \mathrm{K}^{+}, \mathrm{Mg}^{2+}$, $\mathrm{Ca}^{2+}, \mathrm{As}^{2+}, \mathrm{Pb}^{2+}$, and $\mathrm{Hg}^{2+}$ with limited concentrations in accordance with Codex standard mentioned in Table 1 were added individually to $100.0 \mathrm{~mL}$ aliquots of solutions containing $10 \mu \mathrm{g}$ of $\mathrm{Cd}$. The same procedure for extraction on solid phase by Schiff base was followed. The effect of $\mathrm{Cu}$ and Fe ions was not investigated because of precipitate formation in the working $\mathrm{pH}$.

3.8. Analytical Performance. Regression equation, correlation coefficient $\left(R^{2}\right)$, limit of detection (LOD), and preconcentrations factor $(\mathrm{PF})$ were calculated in optimal conditions and summarized in Table 2.

The LOD was calculated as the analyte concentration equal to three times the standard deviation of the blank signal divided by the slope of the calibration curve. The LOD was obtained in the range of $5.0 \mu \mathrm{g} / \mathrm{L}$.

The PF was calculated as the ratio of sample solution volume to eluent solution volume. The PF obtained for solution containing $100.0 \mu \mathrm{g} / \mathrm{L}$ of Cd (II) was 200 .

The real samples were extracted by $\mathrm{C} 18$-bonded silica disk modified with the tetradentate Schiff base followed by FAAS. Analysis of samples showed that they contained trace amount of Cd (II) which were lower than permissible limit in Codex standard. Therefore, all the real salt samples were spiked with reference standard solution at $100.0 \mu \mathrm{g} / \mathrm{L}$ concentration to assess the matrix effects. 
TABLE 2: The limits of detection, regression equations, correlation coefficient, preconcentration factor, recovery, and relative standard deviation for extraction method.

\begin{tabular}{lcccccc}
\hline Analyte & Regression equation & $R^{2}$ & LOD $(\mu \mathrm{g} / \mathrm{L})$ & PF & Recovery $(\%)$ & RSD $(\%)$ \\
\hline Cd ion & $Y=0.368 X+0.126$ & 0.9905 & 5.0 & 200 & $98.0 \pm 0.5$ & $\leq 2$ \\
\hline
\end{tabular}

TABLE 3: Determination of Cd ions in the salt samples.

\begin{tabular}{lcccc}
\hline Sample & $\begin{array}{c}C_{\text {added }} \\
\left(\mu \mathrm{g} \mathrm{L}^{-1}\right)\end{array}$ & $\begin{array}{c}C_{\text {found }} \\
\left(\mu \mathrm{g} \mathrm{L}^{-1}\right)\end{array}$ & $\begin{array}{c}\text { Recovery } \\
(\%)\end{array}$ & $\begin{array}{c}\text { RSD } \\
(\%)\end{array}$ \\
\hline Rahrahak sample & 100.0 & 93.7 & 93.7 & 1.7 \\
Commercial sample & 100.0 & 95.4 & 95.4 & 1.4 \\
\hline
\end{tabular}

Table 3 shows that the results of the four replicate analyses of each sample obtained by the SPE/FAAS method are satisfactorily in agreement with the amounts of Cd (II) added. It is noticeable that the amount of $\mathrm{Cd}$ ion was not detectable in all samples without spiking.

\section{Conclusion}

This paper describes a preconcentration/separation procedure based on solid phase extraction of cadmium in salt samples using a octadecyl silica disk modified by a new pyridine derivative ligand followed by flame atomic absorption spectrometric determination. The proposed method has advantages such as high sample cleanup, efficiency, selectivity, and preconcentration factor. In conclusion, the performance of this procedure has been excellent in extraction of trace amounts of Cd (II) from different salt samples. Furthermore, this method is very environmental friendly, and it can be used in complex matrices with high selectivity.

\section{References}

[1] F. Xie, X. Lin, X. Wu, and Z. Xie, "Solid phase extraction of lead (II), copper (II), cadmium (II) and nickel (II) using gallic acid-modified silica gel prior to determination by flame atomic absorption spectrometry," Talanta, vol. 74, no. 4, pp. 836-843, 2008.

[2] M. Tuzen and M. Soylak, "Multi-element coprecipitation for separation and enrichment of heavy metal ions for their flame atomic absorption spectrometric determinations," Journal of Hazardous Materials, vol. 162, no. 2-3, pp. 724-729, 2009.

[3] A. M. Cheraghali, F. Kobarfard, and N. Faeizy, "Heavy metals contamination of table salt consumed in iran," Iranian Journal of Pharmaceutical Research, vol. 9, no. 2, pp. 129-132, 2010.

[4] C. Duran, A. Gundogdu, V. N. Bulut et al., "Solid-phase extraction of $\mathrm{Mn}(\mathrm{II}), \mathrm{Co}(\mathrm{II}), \mathrm{Ni}(\mathrm{II}), \mathrm{Cu}(\mathrm{II}), \mathrm{Cd}(\mathrm{II})$ and $\mathrm{Pb}(\mathrm{II})$ ions from environmental samples by flame atomic absorption spectrometry (FAAS)," Journal of Hazardous Materials, vol. 146, no. 1-2, pp. 347-355, 2007.

[5] Y. Zhai, Y. Liu, X. Chang, S. Chen, and X. Huang, "Selective solid-phase extraction of trace cadmium(II) with an ionic imprinted polymer prepared from a dual-ligand monomer," Analytica Chimica Acta, vol. 593, no. 1, pp. 123-128, 2007.

[6] H. Ciftci, "Separation and solid phase extraction method for the determination of cadmium in environmental samples," Desalination, vol. 263, no. 1-3, pp. 18-22, 2010.
[7] G. Yang, W. Fen, C. Lei, W. Xiao, and H. Sun, "Study on solid phase extraction and graphite furnace atomic absorption spectrometry for the determination of nickel, silver, cobalt, copper, cadmium and lead with MCI GEL CHP 20 Y as sorbent," Journal of Hazardous Materials, vol. 162, no. 1, pp. 44-49, 2009.

[8] B. Dede, F. Karipcin, and M. Cengiz, "Novel homo- and heteronuclear copper(II) complexes of tetradentate Schiff bases: synthesis, characterization, solvent-extraction and catalase-like activity studies," Journal of Hazardous Materials, vol. 163, no. 2-3, pp. 1148-1156, 2009.

[9] A. Malekpour, S. Hajialigol, and M. A. Taher, "Study on solidphase extraction and flame atomic absorption spectrometry for the selective determination of cadmium in water and plant samples with modified clinoptilolite," Journal of Hazardous Materials, vol. 172, no. 1, pp. 229-233, 2009.

[10] k. J. Brodie and J. P. Matousek, "Determination of cadmium in air by non-flame atomic absorption spectrometry," Analytica Chimica Acta, vol. 69, no. 1, pp. 200-202, 1974.

[11] E. Melek, M. Tuzen, and M. Soylak, "Flame atomic absorption spectrometric determination of cadmium(II) and lead(II) after their solid phase extraction as dibenzyldithiocarbamate chelates on Dowex Optipore V-493," Analytica Chimica Acta, vol. 578, no. 2, pp. 213-219, 2006.

[12] S. P. Dolan and S. G. Capar, "Multi-element analysis of food by microwave digestion and inductively coupled plasmaatomic emission spectrometry," Journal of Food Composition and Analysis, vol. 15, no. 5, pp. 593-615, 2002.

[13] M. Soylak, A. U. Karatepe, L. Elci, and M. Dogan, "Column preconcentration/separation and atomic absorption spectrometric determinations of some heavy metals in table salt samples using amberlite XAD-1180," Turkish Journal of Chemistry, vol. 27, pp. 235-242, 2003.

[14] A. N. Anthemidis, G. A. Zachariadis, C. G. Farastelis, and J. A. Stratis, "On-line liquid-liquid extraction system using a new phase separator for flame atomic absorption spectrometric determination of ultra-trace cadmium in natural waters," Talanta, vol. 62, no. 3, pp. 437-443, 2004.

[15] I. Komjarova and R. Blust, "Comparison of liquid-liquid extraction, solid-phase extraction and co-precipitation preconcentration methods for the determination of cadmium, copper, nickel, lead and zinc in seawater," Analytica Chimica Acta, vol. 576, no. 2, pp. 221-228, 2006.

[16] V. Camel, "Solid phase extraction of trace elements," Spectrochimica Acta B, vol. 58, no. 7, pp. 1177-1233, 2003.

[17] N. Pourreza and H. Zavvar Mousavi, "Determination of cadmium by flame atomic absorption spectrometry after preconcentration on naphthalene-methyltrioctylammonium chloride adsorbent as tetraiodocadmate (II) ions," Analytica Chimica Acta, vol. 503, no. 2, pp. 279-282, 2004.

[18] T. Kumamaru, H. Matsuo, Y. Okamoto, and M. Iked, "Sensitivity enhancement for inductively-coupled plasma atomic emission spectrometry of cadmium by suction-flow on-line ion-exchange preconcentration," Analytica Chimica Acta, vol. 181, pp. 271-275, 1986.

[19] M. Ghaedi, A. Shokrollahi, K. Niknam, E. Niknam, A. Najibi, and M. Soylak, "Cloud point extraction and flame atomic 
absorption spectrometric determination of cadmium(II), lead(II), palladium(II) and silver(I) in environmental samples," Journal of Hazardous Materials, vol. 168, no. 2-3, pp. 1022-1027, 2009.

[20] J. L. Manzoori and G. Karim-Nezhad, "Development of a cloud point extraction and preconcentration method for $\mathrm{Cd}$ and $\mathrm{Ni}$ prior to flame atomic absorption spectrometric determination," Analytica Chimica Acta, vol. 521, no. 2, pp. 173-177, 2004.

[21] P. Kuban, R. Guchardi, and P. C. Hauser, Trace-metal analysis with separation methods, Trends Anal Chem., vol. 24, pp. 192-198, 2005.

[22] J. Otero-Romaní, A. Moreda-Piñeiro, A. Bermejo-Barrera, and P. Bermejo-Barrera, "Evaluation of commercial C18 cartridges for trace elements solid phase extraction from seawater followed by inductively coupled plasma-optical emission spectrometry determination," Analytica Chimica Acta, vol. 536, no. 1-2, pp. 213-218, 2005.

[23] S. L. C. Ferreira, H. M. C. Andrade, and H. C. dos Santos, "Characterization and determination of the thermodynamic and kinetic properties of the adsorption of the molybdenum(VI)calmagite complex onto active carbon," Journal of Colloid and Interface Science, vol. 270, no. 2, pp. 276-280, 2004.

[24] G. Absalan and M. A. Mehrdjardi, "Separation and preconcentration of silver ion using 2-mercaptobenzothiazole immobilized on surfactant-coated alumina," Separation and Purification Technology, vol. 33, no. 1, pp. 95-101, 2003.

[25] L. Elci, A. A. Kartal, and M. Soylak, "Solid phase extraction method for the determination of iron, lead and chromium by atomic absorption spectrometry using Amberite XAD2000 column in various water samples," Journal of Hazardous Materials, vol. 153, no. 1-2, pp. 454-461, 2008.

[26] V. N. Bulut, A. Gundogdu, C. Duran et al., "A multi-element solid-phase extraction method for trace metals determination in environmental samples on Amberlite XAD-2000," Journal of Hazardous Materials, vol. 146, no. 1-2, pp. 155-163, 2007.

[27] E. M. Soliman, M. E. Mahmoud, and S. A. Ahmed, "Synthesis, characterization and structure effects on selectivity properties of silica gel covalently bonded diethylenetriamine mono- and bissalicyaldehyde and naphthaldehyde schiff's bases towards some heavy metal ions," Talanta, vol. 54, no. 2, pp. 243-253, 2001.

[28] N. Soltanzadeh and A. Morsali, "Metal-organic supramolecular assemblies generated from bismuth(III) bromide and polyimine ligands," Polyhedron, vol. 28, no. 4, pp. 703-710, 2009.

[29] G. Mahmoudi and A. Morsali, "Crystal-to-crystal transformation from a weak hydrogen-bonded two-dimensional network structure to a two-dimensional coordination polymer on heating," Crystal Growth and Design, vol. 8, no. 2, pp. 391-394, 2008.

[30] G. Mahmoudi and A. Morsali, "Mercury(II) iodide coordination polymers generated from polyimine ligands," Polyhedron, vol. 27, no. 3, pp. 1070-1078, 2008.

[31] E. Melek, M. Tuzen, and M. Soylak, "Flame atomic absorption spectrometric determinationof cadmium(II) and lead(II) after their solid phase extraction as dibenzyldithiocarbamate chelates on Dowex Optipore V-493," Analytica Chimica Acta, vol. 578, no. 2, pp. 213-219, 2006.

[32] L. A. Saghatforoush, A. Aminkhani, S. Ershad, G. Karimnezhad, S. Ghammamy, and R. Kabiri, "Preparation of zinc (II) and cadmium (II) complexes of the tetradentate Schiff base ligand 2-((E)-(2-(2-(pyridine-2-yl)-ethylthio)ethylimino)methyl)-4bromophenol (PytBrsalH)," Molecules, vol. 13, no. 4, pp. 804-811, 2008.
[33] D. Kara, A. Fisher, and S. J. Hill, "Determination of trace heavy metals in soil and sediments by atomic spectrometry following preconcentration with Schiff bases on Amberlite XAD-4," Journal of Hazardous Materials, vol. 165, no. 1-3, pp. 1165-1169, 2009. 

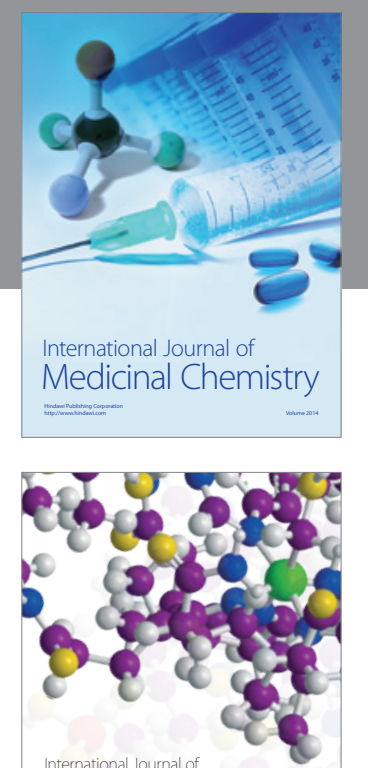

\section{Carbohydrate} Chemistry

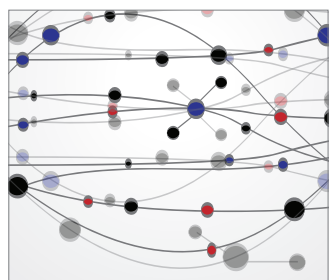

The Scientific World Journal
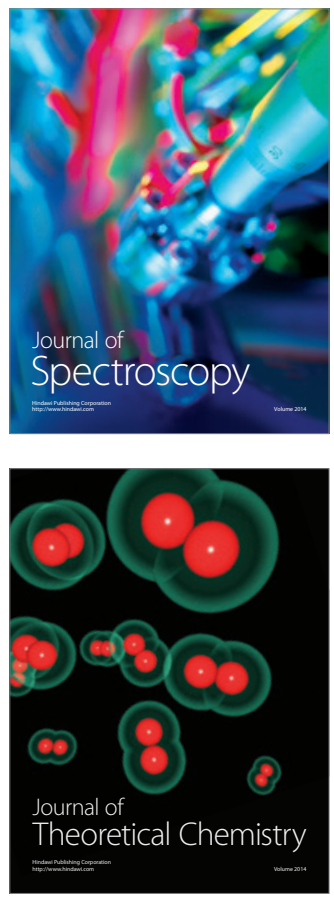
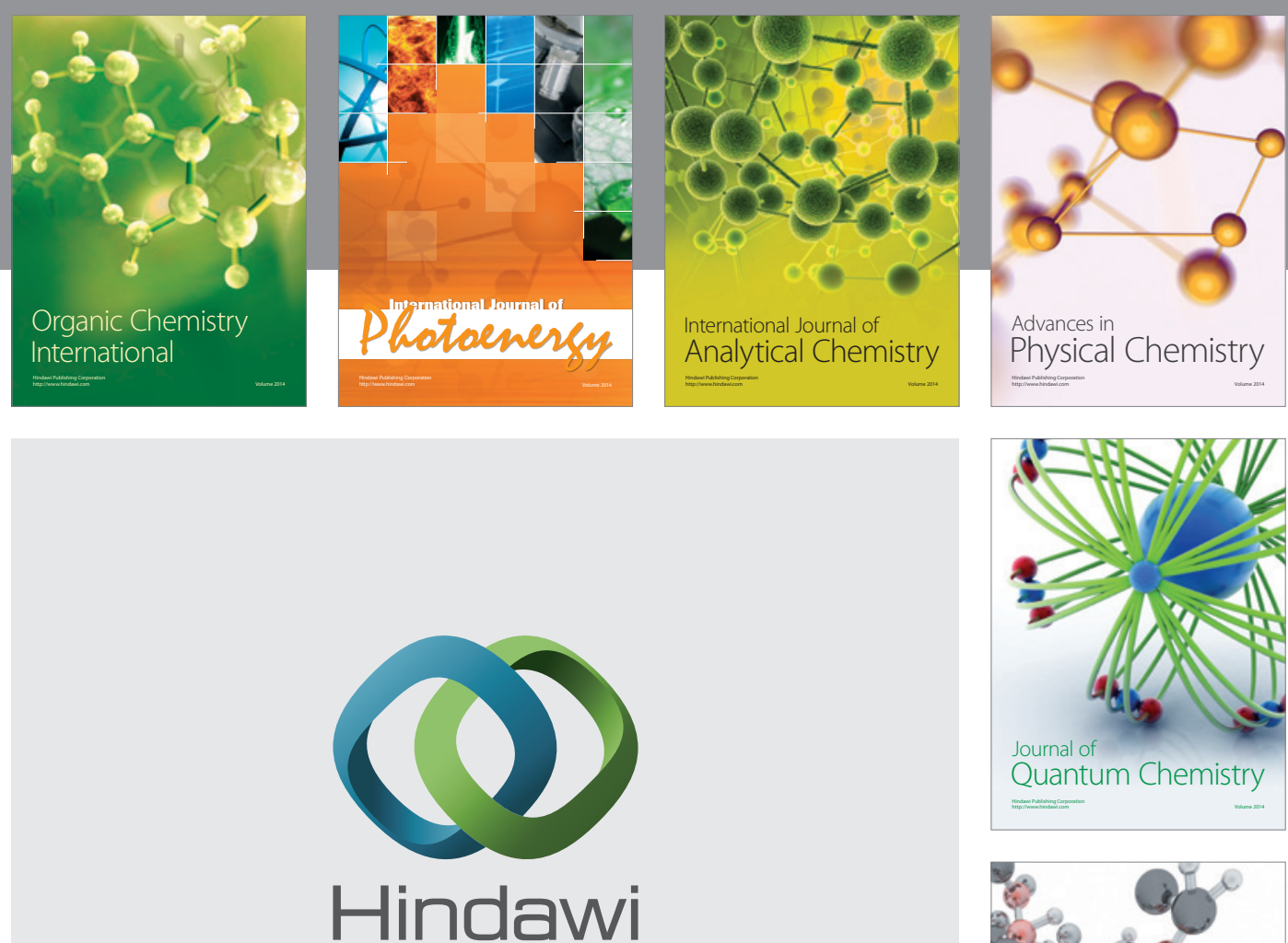

Submit your manuscripts at

http://www.hindawi.com

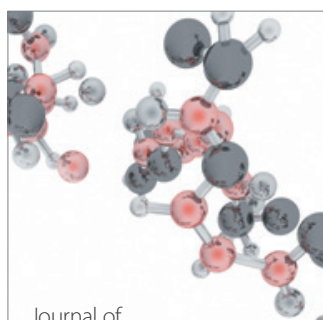

Analytical Methods

in Chemistry

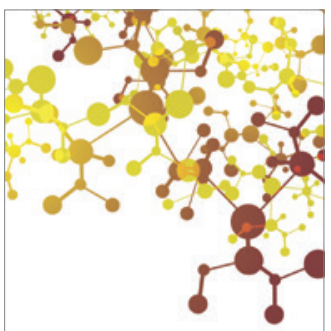

Journal of

Applied Chemistry

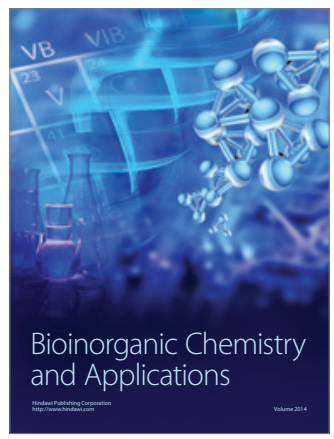

Inorganic Chemistry
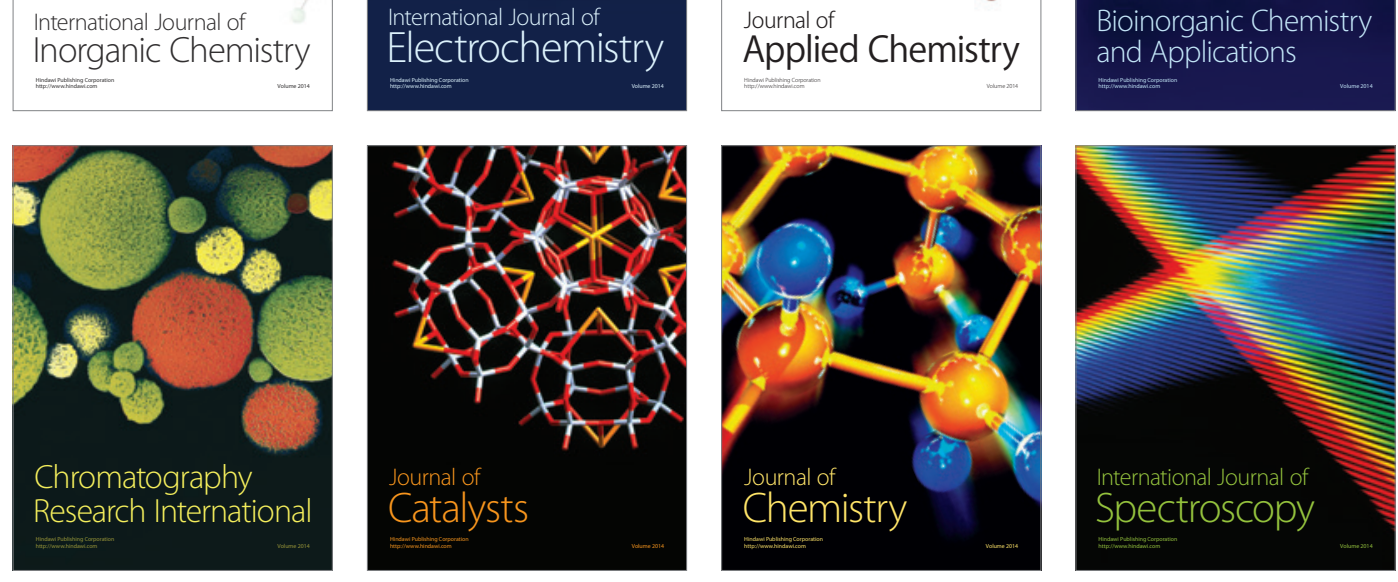